\title{
Changes in potassium pools in Paraná soils under successive cropping and potassium fertilization
}

\author{
Alterações das formas de potássio em solos do Estado do Paraná \\ submetidos à cultivos sucessivos e adubação potássica
}

Fábio Steiner ${ }^{*}$; Maria do Carmo Lana²; Tiago Zoz ${ }^{1}$, Jucenei Fernando Frandoloso ${ }^{3}$

\begin{abstract}
The changes in soil potassium pools under intense cropping and fertilized with potash fertilizer are still little known to the soils of Paraná State. The effects of potassium fertilization and successive cropping on changes in $\mathrm{K}$ pools in different soils of Paraná, Brazil, were investigated in this study. Twelve soil samples, collected from the upper layer $0-0.20 \mathrm{~m}$, were fertilized or not with $\mathrm{K}$ and subjected to six successive cropping (i.e., soybean, pearl millet, wheat, common beans, soybean and maize). All the crops were grown for 45 days, and at the end of the second, fourth and sixth cropping, the soil from each pot was sampled to determination of the total $\mathrm{K}$, non-exchangeable $\mathrm{K}$, exchangeable $\mathrm{K}$ and solution $\mathrm{K}$. The result showed that the soil potassium pools varied widely. Total $\mathrm{K}$ concentration ranged from 547 to $15,563 \mathrm{mg} \mathrm{kg}^{-1}\left(4,714 \mathrm{mg} \mathrm{kg}^{-1}\right.$, on average). On the average, structural $\mathrm{K}$, non-exchangeable $\mathrm{K}$, exchangeable $\mathrm{K}$ and solution $\mathrm{K}$ of the soils constituted 84.0, $11.3,4.6$ and $0.1 \%$ of the total $\mathrm{K}$, respectively. Soils differ in the ability to supply potassium to the plants in the short to medium term, due to the wide range of parent material and the degree of soil weathering. When the soils were not fertilized with $\mathrm{K}$, the successive cropping of plants resulted in a continuous process of depletion of nonexchangeable $\mathrm{K}$ and exchangeable $\mathrm{K}$ pools; however, this depletion was less pronounced in soils with higher potential buffer capacity of $\mathrm{K}$. The concentrations of $\mathrm{K}$ non-exchangeable and exchangeable $\mathrm{K}$ were increased with the addition of potassium fertilizers, indicating the occurrence of $\mathrm{K}$ fixation in soil. After the second cropping, the soil exchangeable K levels remained constant with values of 141 and 36 $\mathrm{mg} \mathrm{kg}{ }^{-1}$, respectively, with and without the addition of $\mathrm{K}$ fertilizer, reflecting in establishing of a new dynamic equilibrium of $\mathrm{K}$ in the soil.
\end{abstract}

Key words: Potassium availability, non-exchangeable K, exchangeable K, potassium supply power, intense cropping

\section{Resumo}

As alterações nas formas químicas de potássio $(\mathrm{K})$ em solos cultivados e submetidos à fertilização potássica, ainda, são pouco conhecidas para os solos do Estado do Paraná. Neste estudo, os efeitos de cultivos sucessivos e da fertilização potássica nas alterações das formas de $\mathrm{K}$ foram estudados em solos com diferentes características físico-químicas do Estado do Paraná. Amostras de 12 solos coletadas da camada de 0-20 cm de profundidade, foram submetidas à adição ou não de fertilizante potássico e a seis cultivos sucessivos de plantas (soja, milheto, trigo, feijão, soja e milho). Em todos os cultivos as plantas foram cultivadas por um período de 40 dias. Após o segundo, quarto e sexto cultivo foram coletadas

\footnotetext{
${ }^{1}$ Profs., Universidade Estadual de Mato Grosso do Sul, UEMS, Cassilândia, MS. Brasil. E-mail: steiner@uems.br; zoz@uems.br

${ }^{2}$ Prof ${ }^{a}$, Universidade Estadual do Oeste do Paraná, UNIOESTE, Marechal Cândido Rondon, PR. Brasil. E-mail: maria.lana@ unioeste.br

${ }^{3}$ Pesquisador, UNIOESTE, Marechal Cândido Rondon, PR. Brasil. E-mail: juceneiff@hotmail.com

* Author for correspondence
} 
amostras de solos para a determinação dos teores de K total, K não-trocável, K trocável e K na solução. Os solos diferenciaram-se na capacidade de suprir $\mathrm{K}$ às plantas a curto e médio prazo. A absorção de $\mathrm{K}$ pelas plantas em cultivos sucessivos, sem a adição de fertilizante potássico, desencadeou um processo contínuo de exaustão de formas não-trocáveis e trocáveis de $\mathrm{K}$ no solo, sendo menos acentuada nos solos com maior poder tampão de potássio. Os teores de K não-trocável e K trocável aumentaram com a adição de fertilizantes potássicos, indicando fixação de K pelo solo. Após o segundo cultivo de plantas os teores de $\mathrm{K}$ trocável mantiveram-se constantes com valores médios de $141 \mathrm{mg} \mathrm{kg}^{-1}$ (com a adição de $\mathrm{K})$ e $36 \mathrm{mg} \mathrm{kg}^{-1}$ (sem adição de K), expressando um novo equilíbrio dinâmico do K no solo.

Palavras-chave: Disponibilidade de potássio, K não-trocável, K trocável, poder tampão de potássio, cultivo intensivo

\section{Introduction}

Soil potassium $(\mathrm{K})$ reserves constitute an important factor for crop yields. In general, most soils contain between 600 and $19,000 \mathrm{mg} \mathrm{kg}^{-1}$ of $\mathrm{K}$, however, the major portion of these K (90 to $98 \%$ ) is tied up as a structure component of primary and secondary minerals (structural $\mathrm{K}$ ), and only 0.1 to $2 \%$ is readily available for use by plants (SPARKS, 2000). According to Sparks and Huang (1985), soil potassium includes the solution $\mathrm{K}$, exchangeable $\mathrm{K}$, non-exchangeable $\mathrm{K}$ and structural $\mathrm{K}$, and these pools are in equilibrium, following a gradient in which its availability decreases. Understanding the mechanisms that involve release and fixation of $\mathrm{K}$ in soil is important because soils may contain widely variable pools of $\mathrm{K}$ that are potentially mobilized by chemical weathering of soil minerals (SIMONSSON et al., 2009).

In tropical soils, with predominance of low activity clay minerals as kaolinite and, iron and aluminum (hydr)oxides, the solution and exchangeable $\mathrm{K}$ are the most important pools of this nutrient in the soil and known as the readily available K pool to plants (SHAIKH et al., 2007). However, the available $\mathrm{K}$ pool is relatively low and corresponds to crop demand during only a few years of intense cropping and the release of $\mathrm{K}$ from nonexchangeable sources can contribute significantly to plant $\mathrm{K}$ nutrition in some soils in the short and medium term (SIMONSSON et al., 2007; STEINER et al., 2012; ROSOLEM et al., 2012). When solution and exchangeable $\mathrm{K}$ are reduced to low levels by plant uptake, non-exchangeable $\mathrm{K}$ can be released from clay interlayers (BORTOLUZZI et al., 2005). Therefore, for sustainable crop production, the available K must be continually replenished through non-exchangeable and mineral $\mathrm{K}$ reserves.

For the appropriate management of $\mathrm{K}$ fertilization is important assess the availability of different soil $\mathrm{K}$ pools and their influences on $\mathrm{K}$ dynamic in the soil profile. This is because the insufficient fertilizer application may lead to depletion of the soil $\mathrm{K}$ reserves (SINGH et al., 2002; BORTOLUZZI et al., 2005; ROSOLEM et al., 2012; STEINER et al., 2012). On the other hand, the excessive fertilizer rates may result in low nutrient use efficiency (BALIGAR et al., 2001), as well as intensify K losses by erosion and leaching (ERNANI et al., 2007; WERLE et al., 2008; ROSOLEM et al., 2010). Soil K dynamic depends on type and quality of clay, soil texture, $\mathrm{pH}$, soil cation exchange capacity (CEC), and the ratio of calcium $\left(\mathrm{Ca}^{+2}\right)+$ magnesium $\left(\mathrm{Mg}^{+2}\right) / \mathrm{K}^{+}$(ROSOLEM et al., 2010). These factors regulate the exchangeable/solution $\mathrm{K}$ ratio and $\mathrm{K}$ availability. Thus, the K availability depends of soil $\mathrm{K}$ pools and the amount of $\mathrm{K}$ stored in each pool (ROSOLEM et al., 1988).

The intense cropping of $\mathrm{K}$-demanding crops and/or potash fertilizer application may affect the relation between soil $\mathrm{K}$ pools and its availability, leading to changes in clay mineral composition (VELDE; PECK, 2002; PERNES-DEBUYSER et al., 2003; BORTOLUZZI et al., 2005; ROSOLEM et al., 2012). Borkert et al. (1997) observed a marked decrease in soil exchangeable $\mathrm{K}$ concentration during successive years of soybean 
crops and reported that it would be necessary to apply at least $80 \mathrm{~kg} \mathrm{ha}^{-1} \mathrm{yr}^{-1}$ of $\mathrm{K}_{2} \mathrm{O}$ to maintain soil exchangeable $\mathrm{K}$ concentrations and avoid depletion of the soil $\mathrm{K}$ reserves. Rosolem et al. (1988) found that when the soil exchangeable $\mathrm{K}$ concentration is less than $60 \mathrm{mg} \mathrm{kg}^{-1}$ there is release of $\mathrm{K}$ from non-exchangeable sources, and these sources would be responsible for the K nutrition of plants, and the maintenance of appropriate levels of soil K. In a sandy clay soil of southern Brazil, Brunetto et al. (2005) found that the soil nonexchangeable $\mathrm{K}$ concentration increased with the use of high rates of potash fertilizer and decreased in the lower rates or when there was no addition of fertilizers. Therefore, knowledge of the balance of soil $\mathrm{K}$ pools serves as support to understand the factors related to the supply of this nutrient to plants, contributing to the understanding of $\mathrm{K}$ dynamics in the soil.

This study was designed to investigate the effects of potassium fertilization and successive cropping on the changes of potassium pools in different soils of Paraná, Brazil.

\section{Material and Methods}

Two pot experiments were carried out in a greenhouse at the West Paraná State University in Marechal Cândido Rondon, Paraná, Brazil (24 $31^{\text {' }}$ $\mathrm{S}, 54^{\circ} 01^{\prime} \mathrm{W}$, and altitude of $420 \mathrm{~m}$ ) to study the effect of $\mathrm{K}$ fertilization and successive cropping on the changes of different soil potassium pools.

Surface samples $(0-0.20 \mathrm{~m})$ from 12 noncultivated soils were collected in areas under native vegetation or ancient reforestation in the State of Paraná, Brazil. The selection of sites for soil sampling was defined based in the different soil parent materials occurring in the State of Paraná (Table 1). Soils were classified according to the Brazilian System of Soil Classification (EMBRAPA, 2013) and Keys to Soil Taxonomy (SOIL SURVEY STAFF, 2010). Properties of the soils were determined by adopting standard procedures, and some characteristics are shown in Table 2.

Table 1. Classification, parent material and sampling site of the 12 soils used in the experiments.

\begin{tabular}{|c|c|c|c|c|}
\hline Soil & $\begin{array}{l}\text { Brazilian soil } \\
\text { classification }^{\dagger}\end{array}$ & USDA soil taxonomy ${ }^{\dagger \dagger}$ & Parent material & Municipality \\
\hline Ox1 & Red Latosol & Rhodic Acrudox & Basalt $^{(1)}$ & Marechal Cândido Rondon \\
\hline Ox2 & Red Latosol & Rhodic Hapludox & Shale $^{(2)}$ & Ponta Grossa \\
\hline Ox3 & Red-Yellow Latosol & Typic Hapludox & Caiuá sandstone ${ }^{(3)}$ & Umuarama \\
\hline Ox4 & Red-Yellow Latosol & Typic Hapludox & Furnas sandstone ${ }^{(4)}$ & Ponta Grossa \\
\hline Alf1 & Red Nitosol & Typic Hapludalf & Basalt $^{(1)}$ & Marechal Cândido Rondon \\
\hline Alf2 & Red Nitosol & Typic Hapludalf & Shale ${ }^{(2)}$ & Ponta Grossa \\
\hline Alf3 & Haplic Plinthosol & Typic Plinthaqualf & Shale $^{(2)}$ & Ponta Grossa \\
\hline Ult1 & Red-Yellow Argisol & Arenic Hapludult & Caiuá sandstone ${ }^{(3)}$ & Umuarama \\
\hline Ult2 & Red-Yellow Argisol & Arenic Hapludult & Basalt $^{(1)}$ & Mercedes \\
\hline Ent & Regolithic Neosol & Typic Usthorthent & Basalt ${ }^{(1)}$ & Marechal Cândido Rondon \\
\hline Ert & Haplic Gleysol & Typic Endoaquert & Alluvial sediments & Marechal Cândido Rondon \\
\hline Ept & Haplic Cambisol & Typic Fragiudept & Furnas sandstone ${ }^{(4)}$ & Ponta Grossa \\
\hline
\end{tabular}

${ }^{\dagger}$ Brazilian soil classification (EMBRAPA, 2013). ${ }^{\dagger}$ Approximate equivalence to USDA soil taxonomy (Soil Survey Staff, 2010).

(1) Basaltic lava flows. Between two consecutive lava flows, there is usually interbedded sedimentary material - sandstones and siltstones.

(2) Shales and siltstones dark gray, very micaceous, laminated, with intercalated sandstones.

(3) Continental sedimentary deposits predominantly of sandstone, quartz, feldspar, chalcedony and opaque.

(4) White sandstones, micaceous, feldspathic, with kaolinitic matrix and cross bedding with conglomeratic levels. 
Lime $(\mathrm{CaO} 25 \%, \mathrm{MgO} 12 \%$ and EEC 96\%) was applied before of the experiments to raise base saturation up to $70 \%$ for clayey soils, $50 \%$ for sandy soils and $60 \%$ for medium texture soils. The soils were then moistened to reach $70 \%$ water retention capacity and incubated for 25 days. Afterwards, 7.5 $\mathrm{kg}$ subsamples of each soil were transferred to $8-\mathrm{L}$ plastic pots with sealed bottoms.

Table 2. Some properties ${ }^{(1)}$ of the soils used in the experiments.

\begin{tabular}{|c|c|c|c|c|c|c|c|c|c|c|c|c|}
\hline Soil & $\mathrm{pH}$ & $\mathrm{ON}$ & & $\mathrm{P}$ & $\mathrm{K}^{+}$ & $\mathrm{Ca}^{2+}$ & $\mathrm{Mg}^{2+}$ & $\mathrm{Al}^{3+}$ & CEC & $\mathrm{V}$ & $\mathrm{K}_{\mathrm{S}}$ & $\mathrm{PBC}^{\mathrm{K}}$ \\
\hline & & $\mathrm{g} \mathrm{dm}$ & & $\mathrm{mg} \mathrm{dm}^{-3}$ & & - & $\mathrm{nol}_{\mathrm{c}} \mathrm{dm}$ & - & ----- & ----- 0 & ---- & \\
\hline Ox1 & 4.6 & 22. & & 9.1 & 0.38 & 3.1 & 1.8 & 0.6 & 14.9 & 35 & 2.6 & 7.8 \\
\hline Ox2 & 3.8 & 21. & & 2.2 & 0.18 & 2.6 & 0.6 & 0.8 & 14.1 & 25 & 1.3 & 3.5 \\
\hline Ox3 & 4.9 & 20. & & 15.4 & 0.16 & 3.9 & 2.2 & 0.2 & 12.9 & 64 & 1.2 & 4.1 \\
\hline Ox4 & 4.2 & 29. & & 13.1 & 0.16 & 3.0 & 1.0 & 0.4 & 13.1 & 31 & 1.2 & 4.7 \\
\hline Alf1 & 5.2 & 32. & & 7.6 & 0.30 & 5.6 & 1.9 & 0.2 & 15.7 & 49 & 1.9 & 9.2 \\
\hline Alf2 & 3.9 & 31.8 & & 9.8 & 0.21 & 2.3 & 0.6 & 1.1 & 16.1 & 19 & 1.3 & 5.8 \\
\hline Alf3 & 3.8 & 31.2 & & 3.1 & 0.19 & 1.2 & 0.4 & 1.2 & 14.2 & 12 & 1.3 & 2.1 \\
\hline Ult1 & 5.2 & 9. & & 20.3 & 0.15 & 2.1 & 0.4 & 0.2 & 6.4 & 43 & 2.3 & 1.3 \\
\hline Ult2 & 3.7 & 30. & & 10.7 & 0.34 & 6.1 & 1.7 & 3.4 & 16.6 & 49 & 2.0 & 12.8 \\
\hline Ent & 5.1 & 15. & & 11.8 & 0.37 & 5.9 & 2.3 & 0.2 & 15.3 & 56 & 2.4 & 10.9 \\
\hline Ert & 3.6 & $20 .^{\circ}$ & & 2.8 & 0.12 & 4.4 & 1.4 & 3.5 & 17.5 & 34 & 0.7 & 6.7 \\
\hline Ept & 5.2 & 16. & & 9.5 & 0.26 & 2.8 & 1.2 & 0.1 & 9.8 & 41 & 2.6 & 2.6 \\
\hline \multirow{2}{*}{ Soil } & \multicolumn{3}{|c|}{ Soil particle size } & \multirow{2}{*}{$\mathrm{BD}$} & \multirow{2}{*}{$\mathrm{PD}$} & \multirow[b]{2}{*}{$\theta_{\mathrm{v}}$} & \multirow{2}{*}{$\mathrm{SiO}_{2}$} & \multirow{2}{*}{$\mathrm{Fe}_{2} \mathrm{O}_{3}$} & \multirow{2}{*}{$\mathrm{Al}_{2} \mathrm{O}_{3}$} & \multirow{2}{*}{$\mathrm{TiO}_{2}$} & \multirow{2}{*}{$\mathrm{Ki}$} & \multirow{2}{*}{$\mathrm{Kr}$} \\
\hline & Sand & Silt & Clay & & & & & & & & & \\
\hline & \multicolumn{3}{|c|}{------- g kg $^{-1}$} & \multicolumn{2}{|c|}{$\mathrm{kg} \mathrm{dm}^{-3}$} & \multicolumn{6}{|c|}{ 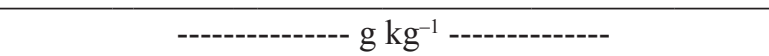 } & \\
\hline Ox1 & 90 & 10 & 900 & 1.05 & 2.31 & 386 & 234 & 198 & 223 & 394 & 1.79 & 1.14 \\
\hline Ox2 & 90 & 125 & 785 & 0.94 & 2.33 & 262 & 101 & 97 & 264 & 101 & 0.65 & 0.53 \\
\hline Ox3 & 690 & 60 & 250 & 1.21 & 2.69 & 314 & 65 & 38 & 75 & 107 & 1.47 & 1.12 \\
\hline Ox4 & 675 & 10 & 315 & 1.30 & 2.68 & 206 & 41 & 33 & 109 & 44 & 0.64 & 0.54 \\
\hline Alf1 & 240 & 210 & 550 & 1.05 & 2.44 & 406 & 209 & 169 & 179 & 437 & 1.98 & 1.24 \\
\hline Alf2 & 80 & 140 & 780 & 0.92 & 2.42 & 450 & 117 & 78 & 220 & 114 & 0.90 & 0.74 \\
\hline Alf3 & 215 & 170 & 615 & 0.94 & 2.65 & 250 & 114 & 103 & 289 & 120 & 0.67 & 0.55 \\
\hline Ult1 & 895 & 20 & 85 & 1.52 & 2.69 & 204 & 18 & 24 & 28 & 67 & 1.11 & 0.71 \\
\hline Ult2 & 155 & 145 & 700 & 1.09 & 2.62 & 318 & 206 & 162 & 197 & 34 & 1.78 & 1.16 \\
\hline Ent & 180 & 185 & 635 & 1.11 & 2.63 & 420 & 221 & 196 & 153 & 289 & 2.46 & 1.35 \\
\hline Ert & 110 & 440 & 450 & 1.16 & 2.43 & 256 & 161 & 66 & 83 & 345 & 3.29 & 2.19 \\
\hline Ept & 755 & 10 & 235 & 1.21 & 2.62 & 254 & 43 & 25 & 137 & 49 & 0.54 & 0.48 \\
\hline
\end{tabular}

(1) $\mathrm{pH}$ in $0.01 \mathrm{~mol} \mathrm{~L}^{-1} \mathrm{CaCl}_{2}$, soil:solution ratio (1:2.5). OM: Organic matter, Walkley-Black method. P and $\mathrm{K}$ were extracted by Mehlich-1 solution. $\mathrm{Ca}, \mathrm{Mg}$ and $\mathrm{Al}$ were extracted by $1 \mathrm{~mol} \mathrm{~L}{ }^{-1} \mathrm{KCl}$ solution. $\mathrm{CEC}$ : cationic exchange capacity was estimated by the summation method $(\mathrm{CEC}=\mathrm{Ca}+\mathrm{Mg}+\mathrm{K})$. V: soil base saturation. $\mathrm{K}_{\mathrm{S}}$ : percent $\mathrm{K}$ saturation of soil. $\mathrm{PBC}^{\mathrm{K}}$ : potential buffering capacity of $\mathrm{K}\left[\right.$ in $\left.\left(\mathrm{mmol}_{\mathrm{c}} \mathrm{kg}^{-1}\right) /\left(\mathrm{mmol} \mathrm{L}^{-1}\right)^{1 / 2}\right]$ determined as described by Mielniczuk (1978). Particle size analysis was performed by the pipette method (Embrapa, 1997). BD: bulk density measured by the graduated cylinder method (Embrapa, 1997). PD: Particle density (Embrapa, 1997). $\theta_{\mathrm{v}}$ : soil volumetric moisture content at field capacity measured as described by Luchese et al. (2001). The Fe and $\mathrm{Al}$ contents, associated to the secondary minerals, were extracted with $9 \mathrm{~mol} \mathrm{~L}^{-1} \mathrm{H}_{2} \mathrm{SO}_{4}$ solution, and Si was removed with $\mathrm{NaOH}$ from the residue of the acid attack, and values expressed in the form of oxides (Embrapa, 1997). Ki: weathering index calculated by the molar ratio $\mathrm{SiO}_{2} / \mathrm{Al}_{2} \mathrm{O}_{3}$. Kr: molar ratio $\mathrm{SiO}_{2} / \mathrm{Al}_{2} \mathrm{O}_{3}+\mathrm{Fe}_{2} \mathrm{O}_{3}$. 
In greenhouse conditions, the soils were subjected to six successive cropping of plants: $\left(1^{\text {st }}\right)$ soybean, $\left(2^{\text {nd }}\right)$ pearl millet $\left(3^{\text {rd }}\right)$ wheat, $\left(4^{\text {th }}\right)$ common beans, $\left(5^{\text {th }}\right)$ soybeans, and $\left(6^{\text {th }}\right)$ maize and two $\mathrm{K}$ fertilization levels [no fertilized or fertilized with potash fertilizer]. The treatments consisted of 12 soils and the addition $(+\mathrm{K})$ or not $(-\mathrm{K})$ of potassium fertilizer, arranged in a randomized block design in a factorial design with four replications. Potassium fertilization was performed with potassium chloride $(\mathrm{KCl})$ in amounts equivalent to raise the percent $\mathrm{K}$ saturation up to $6 \%$.

Before sowing of crops, the soils were fertilized with $80 \mathrm{mg} \mathrm{kg}^{-1}$ of $\mathrm{N}$ as ammonium nitrate, 120 $\mathrm{mg} \mathrm{kg} \mathrm{kg}^{-1}$ of as simple superphosphate, $5 \mathrm{mg} \mathrm{kg}^{-1}$ of $\mathrm{S}$ as calcium sulfate, $5 \mathrm{mg} \mathrm{kg}^{-1}$ of $\mathrm{Cu}$ as copper sulfate, $5 \mathrm{mg} \mathrm{kg}^{-1}$ of $\mathrm{Zn}$ zinc sulfate, $1 \mathrm{mg} \mathrm{kg}^{-1}$ of Mo as ammonium molybdate and $2 \mathrm{mg} \mathrm{kg}^{-1}$ of $\mathrm{B}$ as boric acid. At 15 and 30 days after plant emergence were also applied $40 \mathrm{mg} \mathrm{kg}^{-1}$ of $\mathrm{N}$ as urea solution. Soil moisture was monitored daily and adjusted to $80 \%$ of the water retention capacity of soils.

All the crops were grown for 45 days, and at the end of the $2^{\text {nd }}, 4^{\text {th }}$ and $6^{\text {th }}$ cropping, the soil from each pot was sampled, air-dried and ground to pass through a $2.0 \mathrm{~mm}$ mesh screen. Soil total $\mathrm{K}$ was determined via wet digestion with concentrated acid [hydrofluoric acid (HF), perchloric acid $\left(\mathrm{HClO}_{4}\right)$ and nitric acid $\left.\left(\mathrm{HNO}_{3}\right)\right]$ as described by Embrapa (1997). Exchangeable $\mathrm{K}$ was extracted by the $1.0 \mathrm{~mol} \mathrm{~L}^{-1}$ ammonium acetate solution $\left(\mathrm{CH}_{3} \mathrm{COONH}_{4}\right)$ buffered to $\mathrm{pH} 7.0$ (SANZONOWICZ; MIELNICZUK, 1985). Nonexchangeable $\mathrm{K}$ was obtained by the difference between amount of $\mathrm{K}$ extracted with boiling 1.0 mol L ${ }^{-1} \mathrm{HNO}_{3}$ and $\mathrm{K}$ extracted with ammonium acetate solution (KNUDSEN et al., 1982). The amount of available $\mathrm{K}$ was extracted by Mehlich-1 $\left(0.05 \mathrm{~mol} \mathrm{~L}^{-1} \mathrm{HCl}+0.0125 \mathrm{~mol} \mathrm{~L}^{-1} \mathrm{H}_{2} \mathrm{SO}_{4}\right.$; $\left.\mathrm{pH} 1.2\right)$ as described by Tedesco et al. (1995). Solution K was obtained after equilibration with $1.0 \mathrm{mmol} \mathrm{L} \mathrm{L}^{-1}$ $\mathrm{SrCl}_{2}$ solution in a soil:solution ratio of $1: 10$ for 30 minutes as described by Mielniczuk (1978). In all extracts, $\mathrm{K}$ concentration was meansured by a flame photometer.

Data were subjected to analysis of variance (F-test, $\mathrm{p}<0.05$ ), and the effects of soil type and successive cropping were unfolded for the addition or not of potash fertilizer, and the means compared by Scott-Knott test at the 0.05 level of confidence. All analyses were performed using Sisvar 5.3 software for Windows (Statistical Analysis Software, UFLA, Lavras, MG, BRA).

\section{Results and Discussion}

\section{Soil properties}

The $\mathrm{pH}$ value of the soils after liming varied from 5.6 to 6.4, and soil base saturation varied from 55 to $74 \%$ (data not shown). Organic matter (OM) content was higher than $15 \mathrm{~g} \mathrm{~kg}^{-1}$ for the majority of soils, except for the Arenic Hapludult (Ult1). The Typic Hapludalf (Alf1) had the highest contents of OM (32.7 $\left.\mathrm{g} \mathrm{kg}^{-1}\right)$. Most soils had high levels of readily available $\mathrm{K}$ (available $\mathrm{K} \geq 0.15$ $\mathrm{cmol}_{\mathrm{c}} \mathrm{dm}^{-3}$ ), except for the Typic Endoaquert (Ert) (Table 2). This explains the slight or no response to $\mathrm{K}$ fertilizer observed in most soils in the first soybean cultivation (data not shown). Rhodic Acrudox (Ox1), Rhodic Hapludox (Ox2), Typic Hapludalf (Alf1), Typic Hapludalf (Alf2), Typic Plinthaqualf (Alf3), Arenic Hapludult (Ult 2) and Typic Usthorthent (Ent) were clay texture $(>400$ $\mathrm{g} \mathrm{kg}^{-1}$ of clay), while Typic Endoaquert (Ert) was silty clay $\left(>400 \mathrm{~g} \mathrm{~kg}^{-1}\right.$ of clay and $>400 \mathrm{~kg}^{-1}$ of silt). On the other hand, the Typic Hapludox (Ox3), Typic Hapludox (Ox4) and Typic Fragiudept (Ept) were sandy clay loam (200-350 $\mathrm{g} \mathrm{kg}^{-1}$ of clay), and Arenic Hapludult (Ult1) was sandy $\left(<100 \mathrm{~g} \mathrm{~kg}^{-1}\right.$ of clay) (Table 2).

The potential buffer capacity of $\mathrm{K}\left(\mathrm{PBC}^{\mathrm{K}}\right)$, which measures the ability of the soil to maintain the intensity of $\mathrm{K}$ in the soil solution, varied from 1.3 to $12.8\left(\mathrm{mmol}_{\mathrm{c}} \mathrm{kg}^{-1}\right) /\left(\mathrm{mmol} \mathrm{L}^{-1}\right)^{1 / 2}$ (Table 2$)$. High $\mathrm{PBC}^{\mathrm{K}}$ values were observed in the Arenic 
Hapludult (Ult2), Typic Usthorthent (Ent) and Typic Hapludalf (Alf1), while Arenic Hapludult (Ult1), Typic Plinthaqualf (Alf3) and Typic Fragiudept (Ept) were low (Table 2). A soil with a large $\mathrm{PBC}^{\mathrm{K}}$ will have a greater capacity to maintain the activity of $\mathrm{K}$ in the soil solution. This indicated that soils of high $\mathrm{PBC}^{\mathrm{K}}$ have enough $\mathrm{K}$ in reserve to replenish used $\mathrm{K}$ by crops while those of low $\mathrm{PBC}^{\mathrm{K}}$ will only replace used K slowly. Thus, the release of $\mathrm{K}$ will be rapid and slow accordingly. It then implies that soils with high $\mathrm{PBC}^{\mathrm{K}}$ will be able to maintain solution $\mathrm{K}$ intensity against plant depletion for longer periods of time while those of low values will have low capacity to maintain the activity of $\mathrm{K}$ in the solution and hence frequent fertilization.

\section{Soil K pools}

The soil potassium pools and the contribution of each pool for the total $\mathrm{K}$ varied with soil type and soil parent material (Table 3). Potassium supplying capacity to plants in the short and medium term had great variation between soils. The K supplying capacity is conceived to include $\mathrm{K}$ supplied from soil solution $\mathrm{K}$, exchangeable $\mathrm{K}$ and non-exchangeable $\mathrm{K}$ pools. The order of abundance of the $\mathrm{K}$ pools in the soils is structural $\mathrm{K}>$ non-exchangeable $\mathrm{K}>$ exchangeable $\mathrm{K}>$ solution $\mathrm{K}$ (Table 3 ). Soil total $\mathrm{K}$ concentrations varied from $547 \mathrm{mg} \mathrm{kg}^{-1}$ in the Arenic Hapludult (Ult1) to $15,563 \mathrm{mg} \mathrm{kg}^{-1}$ in the Typic Hapludalf (Alf2) with mean value of 4,714 $\mathrm{mg} \mathrm{kg}{ }^{-1}$. These total $\mathrm{K}$ concentrations are similar to those normally reported for Brazilian soils (SILVA et al., 1995; MELO et al., 2005; KAMINSKI et al., 2007). The soil structural $\mathrm{K}$ constitutes in mean $84.0 \%$ of the total $\mathrm{K}$ ( 66.4 to $96.9 \%$ ), and varied from 368 to $15,083 \mathrm{mg} \mathrm{kg}^{-1}$ (Table 3 ). The $\mathrm{K}$ containing mineral vary with the source of parent material and the degree of weathering (SIMONSSON et al., 2007). The soil exchangeable $K$ varied slightly with mean value of $96 \mathrm{mg} \mathrm{kg}^{-1}$ (49 to $151 \mathrm{mg} \mathrm{kg}{ }^{-1}$ ), it constitutes $4.6 \%$ of the total $\mathrm{K}(0.7$ to $13.1 \%)$. These values were lower than the values for the non- exchangeable $\mathrm{K}$, which constitutes about $11.3 \%$ of the total K (2.4 to $24.5 \%$ ), and varied from 134 to $539 \mathrm{mg} \mathrm{kg}^{-1}$ (Table 3). These data indicate that short-term supply of $\mathrm{K}$ in some soils depends of the release of $\mathrm{K}$ from non-exchangeable sources. In soils of Minas Gerais, Cabbau et al. (2004) found that the exchangeable $\mathrm{K}$ and solution $\mathrm{K}$ were the pools that most contributed to the total $\mathrm{K}$. This higher contribution of non-exchangeable pool to the total $\mathrm{K}$ observed in this study was due to no history of $\mathrm{K}$ fertilization of soils studied.

\section{Soil total $K$}

Soil total K concentration before and after the successive cropping of plants fertilized $(+\mathrm{K})$ and not fertilized $(-\mathrm{K})$ with $\mathrm{K}$ fertilizer are shown in Table 4 . There was wide variation in the total $\mathrm{K}$ concentration of the soils, mainly due to the parent material and the degree of weathering. The lowest concentration of the total $\mathrm{K}$ in Rhodic Acrudox (Ox1) may be due to the high degree of weathering of this soil (weathering index (Ki) of 1.79) and the predominance of kaolinite and $\mathrm{Fe}$ and $\mathrm{Al}$ oxides as dominant clay minerals (Table 2). These clay minerals have small amounts of primary and secondary minerals containing $\mathrm{K}$ in its structure. Silva et al. (2000) also found lower total K concentration in soil with high degree of weathering and/or derived from basic rocks (basalt), which are poor in $\mathrm{K}$ feldspars and phyllosilicates. In a tropical soil of the Ceará State, Diniz et al. (2007) found that $95 \%$ of the clay fraction is constituted of kaolinite.

Soils have been referred to as young, mature, and old, depending on the degree of weathering. The young soils, even derived from basalt (in this case, Alf1 and Ent), may have high levels of total K (Table 4). Soil youth have higher mineral reserves of $\mathrm{K}$ due to the presence of significant amounts of mica and feldspar in the coarse soil fraction, which are important sources of K (SPARKS, 2000). According to these authors, the total $\mathrm{K}$ concentration in the basic rocks (basalt) can reach 7,000 $\mathrm{mg} \mathrm{kg}^{-1}$. 
Table 3. Concentration of the soil potassium pools and contribution of different pools to the total $\mathrm{K}$ in the soils of Paraná State.

\begin{tabular}{|c|c|c|c|c|c|}
\hline Soil & Total K & Structural K & Non-exchangeable K & Exchangeable K & Solution K \\
\hline & ------------- & -------------------------- & $\mathrm{kg}^{-1}$------------------- & ------------------- & $\mathrm{mg} \mathrm{L}^{-1}$ \\
\hline Ox1 & $1,153 \pm 65$ & $771 \pm 51 \quad(66.9)^{\dagger}$ & $231 \pm 15(20.0)$ & $151 \pm 13$ & $8.5 \pm 2$ \\
\hline Ox2 & $8,562 \pm 132$ & $8,042 \pm 116(93.9)$ & $450 \pm 23(5.2)$ & $70 \pm 8 \quad(0.8)$ & $4.4 \pm 1$ \\
\hline Ox3 & $1,003 \pm 43$ & $740 \pm 32 \quad(73.8)$ & $192 \pm 12$ & $74 \pm 9$ & $3.9 \pm 1$ \\
\hline Ox4 & $1,649 \pm 58$ & $1,355 \pm 45 \quad(82.2)$ & $207 \pm 16$ & $87 \pm 10$ & $12.3 \pm 2$ \\
\hline Alf1 & $5,362 \pm 172$ & $4,698 \pm 130(87.6)$ & $539 \pm 28(10.0)$ & $125 \pm 14(2.3)$ & $8.1 \pm 2$ \\
\hline Alf2 & $15,563 \pm 428$ & $15,083 \pm 398 \quad(96.9)$ & $374 \pm 17(2.4)$ & $106 \pm 13(0.7)$ & $9.3 \pm 2$ \\
\hline Alf3 & $7,706 \pm 176$ & $7,373 \pm 150$ & $263 \pm 18$ & $70 \pm 8 \quad(0.9)$ & $2.8 \pm 1$ \\
\hline Ult1 & $547 \pm 32$ & $363 \pm 21 \quad(66.4)$ & $134 \pm 10$ & $49 \pm 6 \quad(8.9)$ & $4.6 \pm 1$ \\
\hline Ult2 & $1,913 \pm 58$ & $1,560 \pm 38 \quad(81.5)$ & $208 \pm 16$ (10.9) & $145 \pm 17(7.6)$ & $8.7 \pm 1$ \\
\hline Ent & $6,982 \pm 212$ & $6,272 \pm 182(89.8)$ & $567 \pm 26(8.1)$ & $147 \pm 14$ & $10.8 \pm 2$ \\
\hline Ert & $4,074 \pm 148$ & $3,635 \pm 120 \quad(89.2)$ & $384 \pm 21 \quad(9.4)$ & $55 \pm 7(1.4)$ & $4.6 \pm 1$ \\
\hline Ept & $2,050 \pm 87$ & $1,730 \pm 64 \quad(84.4)$ & $211 \pm 12(10.3)$ & $109 \pm 12(5.3)$ & $9.4 \pm 2$ \\
\hline
\end{tabular}

${ }^{\dagger}$ Value between parentheses is the percentage contribution of each pool for soil total $\mathrm{K}$.

The lowest concentration of soil total K $(547 \mathrm{mg}$ $\mathrm{kg}^{-1}$ ) in Arenic Hapludult (Ult2) may be due to the sandy texture of the soil (Table 2). Melo et al. (2004) found that the coarse sand fraction has mineralogy composed mainly of quartz. Although some studies have shown the importance of the sand fraction as a reserve of this nutrient (DINIZ et al., 2007), the greater majority of soil $\mathrm{K}$ minerals are found in the clay fraction (MELO et al., 2005).

Higher total $\mathrm{K}$ concentration (Table 4) was observed in the soils (Ox2, Alf2 and Alf3) derived from the Ponta Grossa Formation sediments composed of very micaceous shale's (Table 1). The pellitic sedimentary rocks (shales) can contain up to $30,000 \mathrm{mg} \mathrm{kg}^{-1}$ of $\mathrm{K}$ (SPARKS, 2000). These results are associated with the presence of mica as natural source of $\mathrm{K}$ in its structure. The mineral $\mathrm{K}$ reserves of the soil are found in the primary minerals such as mica and feldspar, and secondary minerals such as illite, vermiculite and interstratified clay minerals (SPARKS; HUANG,
1985). Silva et al. (2000) also found the highest values of total $\mathrm{K}$ in soils derived from pellitic rocks, which according to Melo et al. (2004) are materials relatively rich in $\mathrm{K}$ minerals.

In general, the soil total $\mathrm{K}$ concentration was little affected by successive cropping, regardless of the addition of $\mathrm{K}$ fertilizer (Table 4). This indicates that the structural $\mathrm{K}$ was not easily released to the plants during the six cropping of plants, confirming the results reported by Kaminski et al. (2007) in soils of southern Brazil. However, when the Rhodic Hapludox (Ox2) was not fertilized with $\mathrm{K}$, the total $\mathrm{K}$ concentration of this soil at the end of the sixth cropping was reduced in $14 \%$ (Table 5). These data indicate that besides the non-exchangeable $\mathrm{K}$, the structural $\mathrm{K}$ also contributed to supply of the nutrient to plants. In a clay tropical soil of Jaboticabal, São Paulo, Chiba et al. (2008) found that the addition of potassium fertilizer increased the total content of $\mathrm{K}$ in the soil profile after the second cycle of banana crop. 
Table 4. Total K concentration in the soils of Paraná State before and after the successive cropping of plants fertilized $(+\mathrm{K})$ and no-fertilized $(-\mathrm{K})$ with $\mathrm{K}$ fertilizer.

\begin{tabular}{|c|c|c|c|c|c|c|c|c|c|}
\hline \multirow{2}{*}{$\begin{array}{c}\text { Potassic } \\
\text { fertilization }\end{array}$} & \multirow{2}{*}{ Soil } & \multirow{2}{*}{ Initial } & \multicolumn{6}{|c|}{ Successive cropping ${ }^{\dagger}$} & \multirow{2}{*}{$\mathrm{CV}$} \\
\hline & & & $1^{\text {st }}$ & $2^{\text {nd }}$ & $3^{\text {rd }}$ & $4^{\text {th }}$ & $5^{\text {th }}$ & $6^{\text {th }}$ & \\
\hline \multirow{14}{*}{$+\mathrm{K}$} & & ------------- & - & - & $\mathrm{mg}$ & -1 ----------- & - & ------------ & \multirow{14}{*}{8.6} \\
\hline & Ox1 & $1,153 \mathrm{hA}$ & - & $1,155 \mathrm{hA}$ & - & $1,158 \mathrm{hA}$ & - & $1,164 \mathrm{hA}$ & \\
\hline & $\mathrm{Ox} 2$ & $8,562 \mathrm{bA}$ & - & $8,592 \mathrm{bA}$ & - & $8,623 \mathrm{bA}$ & - & $8,685 \mathrm{bA}$ & \\
\hline & $\mathrm{O} \times 3$ & $1,003 \mathrm{hA}$ & - & $1,013 \mathrm{hA}$ & - & $1,023 \mathrm{hA}$ & - & $1,043 \mathrm{hA}$ & \\
\hline & Ox4 & $1,649 \mathrm{gA}$ & - & $1,649 \mathrm{gA}$ & - & $1,648 \mathrm{gA}$ & - & $1,648 \mathrm{gA}$ & \\
\hline & Alf1 & $5,362 \mathrm{eA}$ & - & $5,363 \mathrm{eA}$ & - & $5,365 \mathrm{eA}$ & - & $5,368 \mathrm{eA}$ & \\
\hline & Alf2 & $15,563 \mathrm{aA}$ & - & $15,621 \mathrm{aA}$ & - & $15,680 \mathrm{aA}$ & - & $15,797 \mathrm{aA}$ & \\
\hline & Alf3 & $7,706 \mathrm{cA}$ & - & $7,756 \mathrm{cA}$ & - & $7,806 \mathrm{cA}$ & - & $7,907 \mathrm{cA}$ & \\
\hline & Ult1 & $547 \mathrm{iA}$ & - & $554 \mathrm{iA}$ & - & $562 \mathrm{iA}$ & - & $577 \mathrm{iA}$ & \\
\hline & Ult2 & $1,913 \mathrm{gA}$ & - & $1,903 \mathrm{gA}$ & - & $1,893 \mathrm{gA}$ & - & $1,919 \mathrm{gA}$ & \\
\hline & Ent & $6,982 \mathrm{dA}$ & - & $7,023 \mathrm{dA}$ & - & $7,063 \mathrm{dA}$ & - & $7,145 \mathrm{dA}$ & \\
\hline & Ert & $4,074 \mathrm{fA}$ & - & $4,101 \mathrm{fA}$ & - & $4,127 \mathrm{fA}$ & - & $4,181 \mathrm{fA}$ & \\
\hline & Ept & $2,050 \mathrm{gA}$ & - & $2,072 \mathrm{gA}$ & - & $2,094 \mathrm{gA}$ & - & $2,138 \mathrm{gA}$ & \\
\hline & Mean & 4,714 & & 4,734 & & 4.754 & & 4,798 & \\
\hline \multirow{13}{*}{$-\mathrm{K}$} & Ox1 & $1,153 \mathrm{hA}$ & - & $1,191 \mathrm{hA}$ & - & $1,129 \mathrm{hA}$ & - & $1,106 \mathrm{hA}$ & \multirow{13}{*}{9.8} \\
\hline & $\mathrm{Ox} 2$ & $8,562 \mathrm{bA}$ & - & $8,006 \mathrm{bA}$ & - & $7,452 \mathrm{bB}$ & - & $7,341 \mathrm{bB}$ & \\
\hline & $\mathrm{Ox} 3$ & $1,003 \mathrm{hA}$ & - & $973 \mathrm{hA}$ & - & $943 \mathrm{hA}$ & - & $922 \mathrm{hA}$ & \\
\hline & Ox4 & $1,649 \mathrm{gA}$ & - & $1,584 \mathrm{gA}$ & - & $1,518 \mathrm{gA}$ & - & $1,386 \mathrm{eA}$ & \\
\hline & Alf1 & $5,362 \mathrm{eA}$ & - & $5,171 \mathrm{eA}$ & - & $4,980 \mathrm{eA}$ & - & $4,898 \mathrm{eA}$ & \\
\hline & Alf2 & $15,563 \mathrm{aA}$ & - & $15,147 \mathrm{aA}$ & - & $14,731 \mathrm{aA}$ & - & $14,599 \mathrm{aA}$ & \\
\hline & Alf3 & $7,706 \mathrm{cA}$ & - & $7,639 \mathrm{cA}$ & - & $7,572 \mathrm{cA}$ & - & $7,437 \mathrm{bA}$ & \\
\hline & Ult1 & $547 \mathrm{iA}$ & - & $520 \mathrm{iA}$ & - & $494 \mathrm{iA}$ & - & $441 \mathrm{iA}$ & \\
\hline & Ult2 & $1,913 \mathrm{gA}$ & - & $1,833 \mathrm{gA}$ & - & $1,752 \mathrm{gA}$ & - & $1,692 \mathrm{gA}$ & \\
\hline & Ent & $6,982 \mathrm{dA}$ & - & $6,833 \mathrm{dA}$ & - & $6,684 \mathrm{dA}$ & - & $6,584 \mathrm{dA}$ & \\
\hline & Ert & $4,074 \mathrm{fA}$ & - & $4,056 \mathrm{fA}$ & - & $4,038 \mathrm{fA}$ & - & $4,003 \mathrm{fA}$ & \\
\hline & Ept & $2,050 \mathrm{gA}$ & - & $2,041 \mathrm{gA}$ & - & $2,032 \mathrm{gA}$ & - & $2,015 \mathrm{gA}$ & \\
\hline & Mean & 4,714 & & 4,583 & & 4,444 & & 4,369 & \\
\hline
\end{tabular}

$\dagger 1^{\text {st: }}$ soybean, $2^{\text {nd }}$ : pearl millet, $3^{\text {nd }}$ : wheat, $4^{\text {nd }}:$ common bean, $5^{\text {nd }}:$ soybean and $6^{\text {nd }}:$ maize. Values represented by the different lower case letters in the column and upper case letters in the lines, show significant differences (Scott-Knott test, P $<0.05)$. $(-)$ not determined.

Soil non-exchangeable $K$

Non-exchangeable K concentration in the soils were affected by successive cropping and potash fertilizer application (Table 5). The higher nonexchangeable $\mathrm{K}$ concentration in Typic Hapludalf (Alf1) and Typic Usthorthent (Ent) was due to higher levels of silt (Table 2) and total K (Table 3) of these soils. Soil young and with high levels of silt have also highest concentrations of non-exchangeable $\mathrm{K}$, and total K (VILLA et al., 2004). Diniz et al. (2007) verified that around $58-67 \%$ of non-exchangeable $\mathrm{K}$ of tropical soils were found in the silt fraction. Confirming the importance of silt fraction for the reserve of non-exchangeable $\mathrm{K}$ in agricultural soils.

When the soils were fertilized with $\mathrm{K}(+\mathrm{K})$, there was an increase in the non-exchangeable $\mathrm{K}$ concentrations in most soils with successive cropping (Table 5). The increase in the non- 
exchangeable $\mathrm{K}$ concentration may be because the changes in soil $\mathrm{K}$ minerals (PERNES-DEBUYSER frequent application of potash fertilizers results in et al., 2003; BORTOLUZZI et al., 2005).

Table 5. Non-exchangeable K concentration in the soils of Paraná State before and after the successive cropping of plants fertilized $(+\mathrm{K})$ and no-fertilized $(-\mathrm{K})$ with $\mathrm{K}$ fertilizer.

\begin{tabular}{|c|c|c|c|c|c|c|c|c|c|}
\hline \multirow{3}{*}{$\begin{array}{c}\text { Potassic } \\
\text { fertilization }\end{array}$} & \multirow{2}{*}{ Soil } & \multirow{2}{*}{ Initial } & \multicolumn{6}{|c|}{ Successive cropping ${ }^{\dagger}$} & \multirow{2}{*}{$\mathbf{C V}$} \\
\hline & & & $1^{\text {st }}$ & $2^{\text {nd }}$ & $3^{\text {rd }}$ & $4^{\text {th }}$ & $5^{\text {th }}$ & $6^{\text {th }}$ & \\
\hline & & \multicolumn{7}{|c|}{ 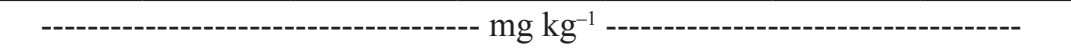 } & \multirow{14}{*}{11.3} \\
\hline \multirow{13}{*}{$+\mathrm{K}$} & Ox1 & $231 \mathrm{~dB}$ & - & $274 \mathrm{dA}$ & - & $233 \mathrm{~dB}$ & - & $301 \mathrm{dA}$ & \\
\hline & $\mathrm{Ox} 2$ & $450 \mathrm{bA}$ & - & $425 \mathrm{cA}$ & - & $392 \mathrm{cB}$ & - & $360 \mathrm{~dB}$ & \\
\hline & $\mathrm{Ox} 3$ & $192 \mathrm{~dB}$ & - & $255 \mathrm{dA}$ & - & $250 \mathrm{dA}$ & - & $231 \mathrm{eA}$ & \\
\hline & $\mathrm{Ox} 4$ & $207 \mathrm{~dB}$ & - & $284 \mathrm{dA}$ & - & $198 \mathrm{eB}$ & - & $214 \mathrm{eB}$ & \\
\hline & Alf1 & $539 \mathrm{aA}$ & - & $530 \mathrm{bA}$ & - & $507 \mathrm{bA}$ & - & $520 \mathrm{bA}$ & \\
\hline & Alf2 & $374 \mathrm{cB}$ & - & $639 \mathrm{aA}$ & - & $665 \mathrm{aA}$ & - & $640 \mathrm{aA}$ & \\
\hline & Alf3 & $263 \mathrm{dA}$ & - & $251 \mathrm{dA}$ & - & $208 \mathrm{~dB}$ & - & $244 \mathrm{eA}$ & \\
\hline & Ult1 & $134 \mathrm{eA}$ & - & $145 \mathrm{eA}$ & - & $150 \mathrm{fA}$ & - & $168 \mathrm{fA}$ & \\
\hline & Ult2 & $208 \mathrm{~dB}$ & - & $472 \mathrm{cA}$ & - & $482 \mathrm{bA}$ & - & $473 \mathrm{cA}$ & \\
\hline & Ent & $567 \mathrm{aA}$ & - & $531 \mathrm{bA}$ & - & $536 \mathrm{bA}$ & - & $556 \mathrm{bA}$ & \\
\hline & Ert & $384 \mathrm{cB}$ & - & $429 \mathrm{cB}$ & - & $499 \mathrm{bA}$ & - & $505 \mathrm{cA}$ & \\
\hline & Ept & $211 \mathrm{~dB}$ & - & $314 \mathrm{dA}$ & - & $313 \mathrm{cA}$ & - & $316 \mathrm{dA}$ & \\
\hline & Mean & 314 & & 379 & & 370 & & 377 & \\
\hline \multirow{13}{*}{$-\mathrm{K}$} & Ox1 & $231 \mathrm{dA}$ & - & $188 \mathrm{cB}$ & - & $139 \mathrm{cC}$ & - & $92 \mathrm{cD}$ & \multirow{13}{*}{13.6} \\
\hline & $\mathrm{Ox} 2$ & $450 \mathrm{bA}$ & - & $280 \mathrm{bB}$ & - & $136 \mathrm{cC}$ & - & $96 \mathrm{cD}$ & \\
\hline & Ox3 & $192 \mathrm{dA}$ & - & $108 \mathrm{eB}$ & - & $106 \mathrm{~dB}$ & - & $93 \mathrm{cB}$ & \\
\hline & Ox4 & $207 \mathrm{dA}$ & - & $148 \mathrm{~dB}$ & - & $121 \mathrm{cC}$ & - & $101 \mathrm{cC}$ & \\
\hline & Alf1 & $539 \mathrm{aA}$ & - & $334 \mathrm{aB}$ & - & $261 \mathrm{aC}$ & - & $179 \mathrm{aD}$ & \\
\hline & Alf2 & $374 \mathrm{cA}$ & - & $264 \mathrm{bB}$ & - & $200 \mathrm{bC}$ & - & $136 \mathrm{bD}$ & \\
\hline & Alf3 & $263 \mathrm{dA}$ & - & $141 \mathrm{dA}$ & - & $97 \mathrm{~dB}$ & - & $59 \mathrm{dC}$ & \\
\hline & Ult1 & $134 \mathrm{eA}$ & - & $98 \mathrm{eB}$ & - & $82 \mathrm{~dB}$ & - & $50 \mathrm{dC}$ & \\
\hline & Ult2 & $208 \mathrm{dA}$ & - & $163 \mathrm{cB}$ & - & $135 \mathrm{cC}$ & - & $97 \mathrm{cD}$ & \\
\hline & Ent & $567 \mathrm{aA}$ & - & $338 \mathrm{aB}$ & - & $192 \mathrm{bC}$ & - & $137 \mathrm{bD}$ & \\
\hline & Ert & $384 \mathrm{cA}$ & - & $265 \mathrm{~dB}$ & - & $126 \mathrm{cC}$ & - & $72 \mathrm{dD}$ & \\
\hline & Ept & $211 \mathrm{dA}$ & - & $132 \mathrm{~dB}$ & - & $113 \mathrm{~dB}$ & - & $60 \mathrm{dC}$ & \\
\hline & Mean & 314 & & 205 & & 142 & & 98 & \\
\hline
\end{tabular}

$\dagger^{\dagger} 1^{\text {st}}$ : soybean, $2^{\text {nd: }}$ pearl millet, $3^{\text {nd. }}$ wheat, $4^{\text {nd. }}$ common bean, $5^{\text {nd. }}:$ soybean and $6^{\text {nd }}:$ maize. Values represented by the different lower case letters in the column and upper case letters in the lines, show significant differences (Scott-Knott test, P $<0.05)$. (-) not determined.

In a clay soil of the Jaboticabal, São Paulo, Chiba et al. (2008) found that the application of $900 \mathrm{~kg} \mathrm{ha}^{-1} \mathrm{yr}^{-1}$ of $\mathrm{K}_{2} \mathrm{O}$ resulted in increased of the non-exchangeable $\mathrm{K}$ concentration of $40 \%$. In a study conducted for 11 years in an Arenic
Hapludult of Santa Maria (RS), Bortoluzzi et al. (2005) found increased of non-exchangeable K with the addition of potassium fertilizers, reflecting in the increased of micaceous minerals (i.e., illite and illite-smectite interstratified clay), compared 
to the soil without $\mathrm{K}$ fertilization.

Velde and Peck (2002) in experiment conducted in silt clay soil for 86 years in Illinois-USA found that crop rotation resulted in changes in soil mineralogy when compared to maize grown in succession. These authors observed changes in the proportion of illite layers in relation to the smectite interstratified mineral. The interstratified illite-smectite clay minerals showed up as a source when the soil solution was poor in $\mathrm{K}$ and as drain when the $\mathrm{K}$ availability was high. According to Pernes-Debuyser et al. (2003), the change of potassium minerals due to weathering process can be minimized with the addition of $\mathrm{K}$ fertilizers.

The intense cropping and/or potash fertilizer application may affect the soil $\mathrm{K}$ dynamic, leading to changes in clay mineral composition (VELDE; PECK, 2002; PERNES-DEBUYSER et al., 2003; BORTOLUZZI et al., 2005; ROSOLEM et al., 2012). Hinsinger and Jaillard (1993) observed the formation of vermiculite, in detriment of illite, in the rhizosphere soil of rye grass plants in only 32 days of grown. Under these conditions, the release of $\mathrm{K}$ from the illite layers, induced by the action of plant roots, was almost complete. Rosolem et al. (2012) showed that the $\mathrm{K}$ depletion in soil under intense cropping can occur in both exchangeable and nonexchangeable pools, even when frequent additions of $\mathrm{K}$ fertilizers are performed. In this study, similar results were observed only in the Ox2, where the non-exchangeable $\mathrm{K}$ concentration decreased from $450 \mathrm{mg} \mathrm{kg}^{-1}$ (before cropping) to $360 \mathrm{mg} \mathrm{kg}^{-1}$ (at the end of the sixth cropping), representing mean reduction of $20 \%$ (Table 5).

When the soils were not fertilized with $\mathrm{K}(-\mathrm{K})$, the non-exchangeable $\mathrm{K}$ concentration decreases in all the soils (Table 5), indicating that these nonexchangeable sources contributed to the supply of K to plants. Initial non-exchangeable $\mathrm{K}$ concentrations ranged from 134 to $567 \mathrm{mg} \mathrm{kg}{ }^{-1}$ (314 mg kg-1, on average), and after the second cropping this concentrations decreased from 98 to $338 \mathrm{mg} \mathrm{kg}^{-1}$
(205 $\mathrm{mg} \mathrm{kg}^{-1}$, on average), indicating mean reduction of $35 \%$. After the fourth and sixth cropping, the nonexchangeable $\mathrm{K}$ ranged from 82 to $261 \mathrm{mg} \mathrm{kg}^{-1}$ (142 $\mathrm{mg} \mathrm{kg}^{-1}$, on average) and from 50 to $179 \mathrm{mg} \mathrm{kg}^{-1}$ (98 $\mathrm{mg} \mathrm{kg}{ }^{-1}$, on average), representing a decrease from the initial mean of 55 and $69 \%$, respectively. The depletion of soil non-exchangeable $\mathrm{K}$ pools with successive cropping, confirms the results reported by Kaminski et al. (2007), who found that the nonexchangeable $\mathrm{K}$ concentration at the end of the $5^{\text {th }}$ cropping was reduced in up to $80 \%$ in the treatment without $\mathrm{K}$ fertilizer.

Fraga et al. (2009) showed that the K supply in the short term ( $1^{\text {st }}$ cropping) was conditioned by the soil exchangeable $\mathrm{K}$ concentration, while in the course of successive cropping ( $2^{\text {nd }}$ and $3^{\text {rd }}$ cropping) this supply was obtained by the release of $\mathrm{K}$ from non-exchangeable sources. In fact, when solution $\mathrm{K}$ and exchangeable $\mathrm{K}$ are reduced to low levels by plant uptake, non-exchangeable $\mathrm{K}$ can be released from clay interlayers (BORTOLUZZI et al., 2005). Non-exchangeable $\mathrm{K}$ can be a source available to plants in the medium term. However, the release rate of $\mathrm{K}$ from non-exchangeable pool is influenced by particle size and chemical and mineralogical composition of the soil (MELO et al., 2005).

\section{Soil exchangeable $K$}

Soil exchangeable K concentration was affected by successive cropping and $\mathrm{K}$ fertilizer application (Table 6). As expected, the K application significantly increased exchangeable $\mathrm{K}$ concentration in most soils (Table 6). These increases, however, were dependents of soil type and initial exchangeable $\mathrm{K}$ concentration.

Initial exchangeable $\mathrm{K}$ concentrations ranged from 49 to $147 \mathrm{mg} \mathrm{kg}^{-1}$ (96 $\mathrm{mg} \mathrm{kg}^{-1}$, on average), and after the second cropping these concentrations increased from 106 to $182 \mathrm{mg} \mathrm{kg}^{-1}$ (136 mg kg-1, on average), indicating mean increase of $42 \%$. After the fourth and sixth cropping, the exchangeable $\mathrm{K}$ 
concentration was constant, ranging from 102 to $168 \mathrm{mg} \mathrm{kg}^{-1}$ (144 $\mathrm{mg} \mathrm{kg}^{-1}$, on average) and from 102 to $185 \mathrm{mg} \mathrm{kg}^{-1}$ (143 $\mathrm{mg} \mathrm{kg}^{-1}$, on average), representing an increase from the initial mean of 50 and $49 \%$, respectively. After the second cropping, the exchangeable $\mathrm{K}$ concentrations were stabilized around $140 \mathrm{mg} \mathrm{kg}{ }^{-1}$. Assuming that there is an equilibrium with non-exchangeable $\mathrm{K}$, in this case, may occur the specific adsorption process of $\mathrm{K}$ ion in the soil mineral phase, as reported by Velde and Peck (2002). This process, however, is limited to clay minerals that have the ability to receive $\mathrm{K}$ in its structure. These exchangeable $\mathrm{K}$ levels is determined by the ability of exchange sites in adsorb $\mathrm{K}$ ion, where its increase is only possible by the increase in the number of such sites.

Table 6. Exchangeable K concentration in the soils of Paraná State before and after the successive cropping of plants fertilized $(+\mathrm{K})$ and no-fertilized $(-\mathrm{K})$ with $\mathrm{K}$ fertilizer.

\begin{tabular}{|c|c|c|c|c|c|c|c|c|c|}
\hline \multirow{2}{*}{$\begin{array}{c}\text { Potassic } \\
\text { fertilization }\end{array}$} & \multirow{2}{*}{ Soil } & \multirow{2}{*}{ Initial } & \multicolumn{6}{|c|}{ Successive cropping ${ }^{\dagger}$} & \multirow{2}{*}{ CV } \\
\hline & & & $1^{\text {st }}$ & $2^{\text {nd }}$ & $3^{\text {rd }}$ & $4^{\text {th }}$ & $5^{\text {th }}$ & $6^{\text {th }}$ & \\
\hline \multirow{14}{*}{$+\mathrm{K}$} & & ------- & --- & --------- & $\mathrm{ng} \mathrm{k}$ & - & - & -------- & \multirow{14}{*}{9.7} \\
\hline & Ox1 & $111 \mathrm{cB}$ & - & $145 \mathrm{bA}$ & - & $147 \mathrm{bA}$ & - & $165 \mathrm{aA}$ & \\
\hline & $\mathrm{Ox} 2$ & $70 \mathrm{~dB}$ & - & $182 \mathrm{aA}$ & - & $168 \mathrm{aA}$ & - & $162 \mathrm{aA}$ & \\
\hline & $\mathrm{Ox} 3$ & $74 \mathrm{~dB}$ & - & $106 \mathrm{cA}$ & - & $117 \mathrm{cA}$ & - & $131 \mathrm{bA}$ & \\
\hline & $\mathrm{Ox} 4$ & $87 \mathrm{~dB}$ & - & $132 \mathrm{bA}$ & - & $102 \mathrm{cA}$ & - & $120 \mathrm{cA}$ & \\
\hline & Alf1 & $125 \mathrm{bB}$ & - & $123 \mathrm{cB}$ & - & $167 \mathrm{aA}$ & - & $179 \mathrm{aA}$ & \\
\hline & Alf2 & $106 \mathrm{cB}$ & - & $113 \mathrm{cB}$ & - & $145 \mathrm{bA}$ & - & $102 \mathrm{cB}$ & \\
\hline & Alf3 & $70 \mathrm{~dB}$ & - & $163 \mathrm{aA}$ & - & $159 \mathrm{aA}$ & - & $155 \mathrm{bA}$ & \\
\hline & Ult1 & $49 \mathrm{eB}$ & - & $115 \mathrm{cA}$ & - & $125 \mathrm{cA}$ & - & $118 \mathrm{cA}$ & \\
\hline & Ult2 & $145 \mathrm{aB}$ & - & $161 \mathrm{aA}$ & - & $145 \mathrm{bB}$ & - & $137 \mathrm{bB}$ & \\
\hline & Ent & $147 \mathrm{aB}$ & - & $141 \mathrm{bB}$ & - & $160 \mathrm{aA}$ & - & $145 \mathrm{bB}$ & \\
\hline & Ert & $55 \mathrm{eC}$ & - & $135 \mathrm{bB}$ & - & $164 \mathrm{aA}$ & - & $185 \mathrm{aA}$ & \\
\hline & Ept & $109 \mathrm{cB}$ & - & $116 \mathrm{cB}$ & - & $134 \mathrm{bA}$ & - & $121 \mathrm{cB}$ & \\
\hline & Mean & 96 & & 136 & & 144 & & 143 & \\
\hline \multirow{13}{*}{$-\mathrm{K}$} & Ox1 & $111 \mathrm{cA}$ & - & $41 \mathrm{~dB}$ & - & $34 \mathrm{cC}$ & - & $33 \mathrm{bC}$ & \multirow{13}{*}{9.0} \\
\hline & Ox2 & $70 \mathrm{dA}$ & - & $50 \mathrm{cB}$ & - & $32 \mathrm{cC}$ & - & $31 \mathrm{bC}$ & \\
\hline & $\mathrm{Ox} 3$ & $74 \mathrm{dA}$ & - & $38 \mathrm{~dB}$ & - & $24 \mathrm{dC}$ & - & $26 \mathrm{cC}$ & \\
\hline & $\mathrm{Ox} 4$ & $87 \mathrm{dA}$ & - & $39 \mathrm{~dB}$ & - & $27 \mathrm{cB}$ & - & $27 \mathrm{cB}$ & \\
\hline & Alf1 & $125 \mathrm{bA}$ & - & $86 \mathrm{aB}$ & - & $55 \mathrm{aC}$ & - & $52 \mathrm{aC}$ & \\
\hline & Alf2 & $106 \mathrm{cA}$ & - & $41 \mathrm{~dB}$ & - & $33 \mathrm{cC}$ & - & $28 \mathrm{cC}$ & \\
\hline & Alf3 & $70 \mathrm{dA}$ & - & $24 \mathrm{fB}$ & - & $24 \mathrm{~dB}$ & - & $20 \mathrm{dC}$ & \\
\hline & Ult1 & $49 \mathrm{eA}$ & - & $24 \mathrm{fB}$ & - & $18 \mathrm{~dB}$ & - & $16 \mathrm{~dB}$ & \\
\hline & Ult2 & $145 \mathrm{aA}$ & - & $66 \mathrm{bB}$ & - & $44 \mathrm{bC}$ & - & $48 \mathrm{aC}$ & \\
\hline & Ent & $147 \mathrm{aA}$ & - & $87 \mathrm{aB}$ & - & $35 \mathrm{cC}$ & - & $34 \mathrm{bC}$ & \\
\hline & Ert & $55 \mathrm{eA}$ & - & $37 \mathrm{~dB}$ & - & $21 \mathrm{dC}$ & - & $20 \mathrm{dC}$ & \\
\hline & Ept & $109 \mathrm{cA}$ & - & $31 \mathrm{eB}$ & - & $32 \mathrm{cB}$ & - & $26 \mathrm{cB}$ & \\
\hline & Mean & 96 & & 47 & & 32 & & 30 & \\
\hline
\end{tabular}

$1^{\text {st: }}$ : soybean, $2^{\text {nd: }}$ pearl millet, $3^{\text {nd. }}$ wheat, $4^{\text {nd. }}$ common bean, $5^{\text {nd. }}$ soybean and $6^{\text {nd: }}:$ maize. Values represented by the different lower case letters in the column and upper case letters in the lines, show significant differences (Scott-Knott test, $\mathrm{P}<0.05)$. $(-)$ not determined. 
When the soils were not fertilized with $\mathrm{K}(-\mathrm{K})$, the exchangeable $\mathrm{K}$ concentration decreases in all the soils (Table 6). Before of the cropping, the exchangeable $\mathrm{K}$ concentrations ranged from 49 to $147 \mathrm{mg} \mathrm{kg}^{-1}$ (96 mg kg${ }^{-1}$, on average), and after the second cropping these concentrations decreased from 24 to $87 \mathrm{mg} \mathrm{kg}^{-1}$ (47 $\mathrm{mg} \mathrm{kg}^{-1}$, on average), indicating mean reduction of $51 \%$. After fourth and sixth cropping, the exchangeable $\mathrm{K}$ concentration was constant, ranging from 18 to $55 \mathrm{mg} \mathrm{kg}^{-1}$ (32 $\mathrm{mg} \mathrm{kg}{ }^{-1}$, on average) and from 16 to $52 \mathrm{mg} \mathrm{kg}^{-1}$ (30 $\mathrm{mg} \mathrm{kg}^{-1}$, on average), representing a decrease from the initial mean of 67 and $69 \%$, respectively (Table 6). The exchangeable $\mathrm{K}$ was stabilized with values around $30 \mathrm{mg} \mathrm{kg}$, indicating that it has reached a balance between pools of exchangeable $\mathrm{K}$ and nonexchangeable $\mathrm{K}$ with a minimum of $\mathrm{K}^{+}$in the soilplant system.

Bortoluzzi et al. (2005) reported similar results in an experiment conducted for 11 years in an Arenic Hapludult. These authors found that when the soil was not fertilized with $\mathrm{K}$, the soil available reduced from $50 \mathrm{mg} \mathrm{kg}^{-1}$ in the beginning of experiment to $38 \mathrm{mg} \mathrm{kg}^{-1}$ in the first year, and $30 \mathrm{mg} \mathrm{kg}^{-1}$ at the end of second year. On the other hand, when the soil was fertilized with $\mathrm{K}$, the soil available $\mathrm{K}$ concentrations increased from $50 \mathrm{mg} \mathrm{kg}^{-1}$ to 80 and $85 \mathrm{mg} \mathrm{kg}^{-1}$, at the end of first and second year, respectively. After this period, the available $\mathrm{K}$ levels in both treatments remained constant around 30 and $90 \mathrm{mg} \mathrm{kg}^{-1}$, respectively, with and without $\mathrm{K}$ fertilization. According to these authors, the maintenance of these levels for nearly a decade with intense cropping of $\mathrm{K}$-demanding crops was only ensured by the release of $\mathrm{K}$ from weathering of $\mathrm{K}$ feldspars and phyllosilicates.

The highest exchangeable $\mathrm{K}$ concentrations observed in Typic Hapludalf (Alf1) (52 mg kg-1) and Arenic Hapludult (Ult2) (48 mg kg-1), especially without the addition of $\mathrm{K}$ fertilizer may be due to higher $\mathrm{PBC}^{\mathrm{K}}$ and CEC of these soils (Table 2). A soil with a high $\mathrm{PBC}^{\mathrm{K}}$ will have a greater capacity to maintain the activity of $\mathrm{K}$ in the soil solution. In turn, the lower exchangeable $\mathrm{K}$ concentration (16 $\mathrm{mg} \mathrm{kg}^{-1}$ ) observed in Arenic Hapludult (Ult1) is due the lowest $\mathrm{PBC}^{\mathrm{K}}$ and $\mathrm{CEC}$ of these soil.

In general, the exchangeable $\mathrm{K}$ concentration of 30 and $140 \mathrm{mg} \mathrm{kg}^{-1}$ may be considered the upper and lower limits for the soil $\mathrm{K}$ balance in case of exhaustion and excess of $\mathrm{K}$, respectively. According to Velde and Peck (2002), these limits are determined mainly by the mineralogy of soils. The results presented here for the exchangeable $\mathrm{K}$ and non-exchangeable $\mathrm{K}$ in the soil obtained without $\mathrm{K}$ fertilization (Tables 5 and 6) confirm the results reported by Rosolem et al. (1988), Bortoluzzi et al. (2005), Brunetto et al. (2005), Kaminski et al. (2007) and Rosolem et al. (2012). These authors showed that the non-exchangeable $\mathrm{K}$ pool can maintain or even enhance soil exchangeable $\mathrm{K}$ reserves in the long term. However, maintaining such a situation in the long term may decrease soil $\mathrm{K}$ reserves, compromising the movement of the nutrient into the soil solution and thus also the successful establishment and growth of crops. In long-term experiments conducted by Borkert et al. (1997) also observed a decrease in exchangeable $\mathrm{K}$ concentration in different soil types during successive years of soybean crop, and found that it would be necessary to apply at least $80 \mathrm{~kg} \mathrm{ha}^{-1} \mathrm{yr}^{-1}$ of $\mathrm{K}_{2} \mathrm{O}$ to maintain soil exchangeable $\mathrm{K}$ concentrations and avoid depletion of the soil $\mathrm{K}$ reserves.

\section{Soil solution $K$}

As expected, the soil solution $\mathrm{K}$ concentration was affected by successive cropping and $\mathrm{K}$ fertilizer application (Table 7). The addition of $\mathrm{K}$ fertilizer $(+\mathrm{K})$ resulted in significant increases in solution $\mathrm{K}$ concentration for most soils (Table 7). These results were expected due to the balance of this pool with soil exchangeable $\mathrm{K}$. Initial solution $\mathrm{K}$ concentration ranged from 2.8 to $12.3 \mathrm{mg} \mathrm{L}^{-1}$ (7.3 $\mathrm{mg} \mathrm{L}^{-1}$, on average), and at the end of the second cropping these concentrations increased from 7.3 to $14.5 \mathrm{mg} \mathrm{L}^{-1}$ (9.4 $\mathrm{mg} \mathrm{L}^{-1}$, on average), indicating 
mean increase of $29 \%$. After the fourth and sixth from 6.6 to $11.7 \mathrm{mg} \mathrm{L}^{-1}\left(9.6 \mathrm{mg} \mathrm{L}^{-1}\right.$, on average), cropping, the $\mathrm{K}$ concentration was constant, ranging representing an increase from the initial mean of 34 from 6.4 to $12.8 \mathrm{mg} \mathrm{L}^{-1}\left(9.8 \mathrm{mg} \mathrm{L}^{-1}\right.$, on average) and and $32 \%$, respectively.

Table 7. Solution K concentration in the soils of Paraná State before and after the successive cropping of plants fertilized $(+\mathrm{K})$ and no-fertilized $(-\mathrm{K})$ with $\mathrm{K}$ fertilizer.

\begin{tabular}{|c|c|c|c|c|c|c|c|c|c|}
\hline \multirow{2}{*}{$\begin{array}{c}\text { Potassic } \\
\text { fertilization }\end{array}$} & \multirow{2}{*}{ Soil } & \multirow{2}{*}{ Initial } & \multicolumn{6}{|c|}{ Successive cropping ${ }^{\dagger}$} & \multirow{2}{*}{$\mathrm{CV}$} \\
\hline & & & $1^{\text {st }}$ & $2^{\text {nd }}$ & $3^{\text {rd }}$ & $4^{\text {th }}$ & $5^{\text {th }}$ & $6^{\text {th }}$ & \\
\hline \multirow{14}{*}{$+\mathrm{K}$} & & -------. & - & -------- & $-m g$ & ---------. & - & -------- & \multirow{14}{*}{15.5} \\
\hline & Ox1 & $8.5 \mathrm{cB}$ & - & $9.4 \mathrm{cA}$ & - & $9.7 \mathrm{bA}$ & - & $10.2 \mathrm{bA}$ & \\
\hline & $\mathrm{Ox} 2$ & $4.4 \mathrm{dC}$ & - & $14.5 \mathrm{aA}$ & - & $12.2 \mathrm{aB}$ & - & $11.3 \mathrm{aB}$ & \\
\hline & $\mathrm{Ox} 3$ & $3.9 \mathrm{~dB}$ & - & $9.8 \mathrm{cA}$ & - & $6.4 \mathrm{cB}$ & - & $6.6 \mathrm{~dB}$ & \\
\hline & $\mathrm{Ox} 4$ & $12.3 \mathrm{aA}$ & - & $6.9 \mathrm{~dB}$ & - & $9.4 \mathrm{bB}$ & - & $8.6 \mathrm{cB}$ & \\
\hline & Alf1 & $8.1 \mathrm{cA}$ & - & $9.6 \mathrm{cA}$ & - & $10.4 \mathrm{bA}$ & - & $9.2 \mathrm{cA}$ & \\
\hline & Alf2 & $9.3 \mathrm{cA}$ & - & $9.3 \mathrm{cA}$ & - & $6.9 \mathrm{cA}$ & - & $9.8 \mathrm{bA}$ & \\
\hline & Alf3 & $2.8 \mathrm{eC}$ & - & $5.8 \mathrm{eB}$ & - & $9.5 \mathrm{bA}$ & - & $8.9 \mathrm{cA}$ & \\
\hline & Ult1 & $4.6 \mathrm{dA}$ & - & $7.3 \mathrm{dA}$ & - & $6.7 \mathrm{cA}$ & - & $6.9 \mathrm{dA}$ & \\
\hline & Ult2 & $8.7 \mathrm{cB}$ & - & $10.4 \mathrm{cA}$ & - & $12.6 \mathrm{aA}$ & - & $10.4 \mathrm{bA}$ & \\
\hline & Ent & $10.8 \mathrm{bB}$ & - & $11.6 \mathrm{bA}$ & - & $12.8 \mathrm{aA}$ & - & $10.8 \mathrm{bB}$ & \\
\hline & Ert & $4.6 \mathrm{~dB}$ & - & $10.4 \mathrm{cA}$ & - & $12.3 \mathrm{aA}$ & - & $11.7 \mathrm{aA}$ & \\
\hline & Ept & $9.4 \mathrm{cA}$ & - & $10.2 \mathrm{cA}$ & - & $10.0 \mathrm{bA}$ & - & $10.5 \mathrm{bA}$ & \\
\hline & Mean & 7.3 & & 9.4 & & 9.8 & & 9.6 & \\
\hline \multirow{13}{*}{$-\mathrm{K}$} & Ox1 & $8.5 \mathrm{dA}$ & - & $3.6 \mathrm{bB}$ & - & $2.2 \mathrm{aC}$ & - & $2.0 \mathrm{aC}$ & \multirow{13}{*}{8.5} \\
\hline & Ox2 & $4.4 \mathrm{eA}$ & - & $2.8 \mathrm{cB}$ & - & $2.0 \mathrm{aC}$ & - & $1.8 \mathrm{aC}$ & \\
\hline & Ox3 & $3.9 \mathrm{eA}$ & - & $1.8 \mathrm{~dB}$ & - & $1.6 \mathrm{cB}$ & - & $1.5 \mathrm{bB}$ & \\
\hline & $\mathrm{Ox} 4$ & $12.3 \mathrm{aA}$ & - & $3.1 \mathrm{cB}$ & - & $1.5 \mathrm{cC}$ & - & $1.3 \mathrm{cC}$ & \\
\hline & Alf1 & $8.1 \mathrm{dA}$ & - & $2.9 \mathrm{cB}$ & - & $2.4 \mathrm{aC}$ & - & $2.2 \mathrm{aC}$ & \\
\hline & Alf2 & $9.3 \mathrm{cA}$ & - & $1.7 \mathrm{~dB}$ & - & $1.6 \mathrm{cB}$ & - & $1.5 \mathrm{bB}$ & \\
\hline & Alf3 & $2.8 \mathrm{fA}$ & - & $1.1 \mathrm{eB}$ & - & $1.3 \mathrm{cB}$ & - & $1.0 \mathrm{cB}$ & \\
\hline & Ult1 & $4.6 \mathrm{eA}$ & - & $1.6 \mathrm{~dB}$ & - & $0.9 \mathrm{dC}$ & - & $1.0 \mathrm{cC}$ & \\
\hline & Ult2 & $8.7 \mathrm{dA}$ & - & $4.4 \mathrm{aB}$ & - & $2.3 \mathrm{aC}$ & - & $1.6 \mathrm{bD}$ & \\
\hline & Ent & $10.8 \mathrm{bA}$ & - & $4.2 \mathrm{aB}$ & - & $2.0 \mathrm{bC}$ & - & $1.9 \mathrm{aC}$ & \\
\hline & Ert & $4.6 \mathrm{eA}$ & - & $2.0 \mathrm{~dB}$ & - & $1.3 \mathrm{cC}$ & - & $1.0 \mathrm{cC}$ & \\
\hline & Ept & $9.4 \mathrm{cA}$ & - & $2.0 \mathrm{~dB}$ & - & $1.9 \mathrm{bB}$ & - & $1.9 \mathrm{aB}$ & \\
\hline & Mean & 7.3 & & 2.6 & & 1.8 & & 1.6 & \\
\hline
\end{tabular}

${ }^{\dagger} 1^{\text {st }}$ : soybean, $2^{\text {nd. }}$ pearl millet, $3^{\text {nd }}:$ wheat, $4^{\text {nd }}:$ common bean, $5^{\text {nd. }}$ soybean and $6^{\text {nd. }}:$ maize. Values represented by the different lower case letters in the column and upper case letters in the lines, show significant differences (Scott-Knott test, $\mathrm{P}<0.05)$. $(-)$ not determined.

When the soils were not fertilized with $\mathrm{K}(-\mathrm{K})$, the initial solution $\mathrm{K}$ concentrations ranged from 2.8 to $12.3 \mathrm{mg} \mathrm{L}^{-1}\left(7.3 \mathrm{mg} \mathrm{L}^{-1}\right.$, on average), and at the end of the second cropping these values decreased from 1.1 to $4.4 \mathrm{mg} \mathrm{L}^{-1}\left(2.6 \mathrm{mg} \mathrm{kg}^{-1}\right.$, on average), indicating mean reduction of $64 \%$. After the fourth and sixth cropping, the solution $\mathrm{K}$ concentration was constant, ranging from 0.9 to 
$2.3 \mathrm{mg} \mathrm{L}^{-1}$ (1.8 $\mathrm{mg} \mathrm{L}^{-1}$, on average) and from 1.0 to $2.2 \mathrm{mg} \mathrm{L}^{-1}$ (1.6 $\mathrm{mg} \mathrm{L}^{-1}$, on average), representing a decrease from the initial mean of 75 and $78 \%$, respectively. These results indicate that has reached a balance between pools of solution $\mathrm{K}$ and exchangeable $\mathrm{K}$ with a minimum of soluble $\mathrm{K}$ in the soil-plant system.

\section{Conclusions}

Soils differ in the ability to supply potassium to the plants in the short to medium term, due to the wide range of parent material and the degree of soil weathering.

When the soils were not fertilized with $\mathrm{K}$, the successive cropping of plants resulted in a continuous process of depletion of non-exchangeable $\mathrm{K}$ and exchangeable K pools; however, this depletion was less pronounced in soils with higher potential buffer capacity of $\mathrm{K}$.

The concentrations of $\mathrm{K}$ non-exchangeable and exchangeable $\mathrm{K}$ were increased with the addition of potassium fertilizers, indicating the occurrence of $\mathrm{K}$ fixation in soil.

After the second cropping, the soil exchangeable $\mathrm{K}$ levels remained constant with values of 141 and $36 \mathrm{mg} \mathrm{kg}^{-1}$, respectively, with and without the addition of $\mathrm{K}$ fertilizer, reflecting in establishing of a new dynamic equilibrium of $\mathrm{K}$ in the soil.

\section{References}

BALIGAR, V. C.; FAGERIA, N. K.; HE, Z. L. Nutrient use efficiency in plants. Communications in Soil Science and Plant Analysis, New York, v. 32, n. 7-8, p. 921-950, 2001.

BORKERT, C. M.; FARIAS, J. R. B.; SFREDO, G. J.; TUTIDA, F.; SPOLADORI, C. L. Resposta da soja à adubação e disponibilidade de potássio em Latossolo Roxo distrófico. Pesquisa Agropecuária Brasileira, Brasília, v. 32, n. 12, p. 1235-1249, 1997.

BORTOLUZZI, E. C.; RHEINHEIMER, D. S.; KAMINSKI, J.; GATIBONI, L. C.; TESSIER, D.
Alterações na mineralogia de um Argissolo do Rio Grande do Sul submetido à fertilização potássica. Revista Brasileira de Ciência do Solo, Viçosa, MG, v. 29, n. 3, p. 327-335, 2005.

BRUNETTO, G.; GATIBONI, L. C.; RHEINHEIMER, D. S.; SAGGIN, A.; KAMINSKI, J. Nível crítico e resposta das culturas ao potássio em um Argissolo sob sistema plantio direto. Revista Brasileira de Ciência do Solo, Viçosa, MG, v. 29, n. 4, p. 565-571, 2005.

CABBAU, A. R.; FAQUIN, V.; FERNANDES, L. A.; ANDRADE, A. T.; LIMA SOBRINHO, R. R. Resposta e níveis críticos de potássio para o arroz cultivado em solos de várzea inundados. Ciência e Agrotecnologia, Lavras, v. 28, n. 1, p. 75-86, 2004.

CHIBA, M. K.; NATALE, W.; CRUZ, M. C. P.; TEIXEIRA, L. A. J.; CENTURION, J. F. Potássio nas frações texturais de Latossolo. Acta Scientiarum. Agronomy, Maringá, v. 30, n. 4, p. 581-587, 2008.

DINIZ, S. F.; BASTOS, F. O. M.; LIMA, R. H. C.; JIMENEZ-RUEDA, J. R. Fontes de potássio não trocável e potássio total em quatro solos do Estado do Ceará. Geociências, São Paulo, v. 26, n. 4, p. 379-386, 2007.

EMPRESA BRASILEIRA DE PESQUISA AGROPECUÁRIA - EMBRAPA. Manual de métodos de análise de solo. Rio de Janeiro: Embrapa Solos, 1997. $212 \mathrm{p}$.

. Sistema brasileiro de classificação de solos. 3 . ed. Rio de Janeiro: Embrapa Solos, 2013. 353 p.

ERNANI, P. R.; BAYER, C.; ALMEIDA, J. A. Mobilidade vertical de cátions influenciada pelo método de aplicação de cloreto de potássio em solos com carga variável. Revista Brasileira de Ciência do Solo, Viçosa, MG, v. 31, n. 2, p. 393-402, 2007.

FRAGA, T. I.; GENRO JUNIOR, S. A.; INDA, A. V.; ANGHINONI, I. Suprimento de potássio e mineralogia de solos de várzea sob cultivos sucessivos de arroz irrigado. Revista Brasileira de Ciência do Solo, Viçosa, MG, v. 33, n. 3, p. 497-506, 2009.

HINSINGER, P.; JAILLARD, B. Root-induced release of interlayer potassium and vermiculitization of hlogopite as related to potassium depletion in the rhizosphere of ryegrass. European Journal of Soil Science, Oxford, v. 44, n. 3, p. 525-534, 1993.

KAMINSKI, J.; BRUNETTO, G.; MOTERLE, D. F.; RHEINHEIMER, D. S. Depleção de formas de potássio do solo afetada por cultivos sucessivos. Revista Brasileira de Ciência do Solo, Viçosa, MG, v. 31, n. 5, p. 1003-1010, 2007. 
KNUDSEN, D.; PETERSON, G. A.; PRATT, P. F. Lithium, sodium, and potassium. In: PAGE, A. L. (Ed.). Methods of soil analysis. Part 2. $2^{\text {th }}$ ed. Madison: ASA, 1982. p. 225-246.

LUCHESE, E. B.; LENZI, E.; FAVERO, L. O. B. Química dos solos. Rio de Janeiro: Freitas Bastos, 2001. $159 \mathrm{p}$.

MELO, V. F.; CORRÊA, G. F.; RIBEIRO, A. N.; MASCHIO, P. A. Cinética de liberação de potássio e magnésio pelos minerais da fração areia de solos do Triângulo Mineiro. Revista Brasileira de Ciência do Solo, Viçosa, MG, v. 29, n. 4, p. 533-545, 2005.

MELO, V. F.; RIBEIRO, A. N.; MASCHIO, P. A.; CORRÊA, G. F.; LIMA, V. C. Mineralogia e formas de potássio e magnésio em diferentes classes de pesos e tamanhos da fração areia de solos do Triângulo Mineiro. Revista Brasileira de Ciência do Solo, Viçosa, MG, v. 28, n. 2, p. 219-231, 2004.

MIELNICZUK, J. O potássio no solo. 4. ed. Piracicaba: Potafós, 1978. 79 p. (Boletim técnico, 2).

PERNES-DEBUYSER, A.; PERNES, M.; VELDE, B.; TESSIER, D. Soil mineralogy evolution in the INRA 42 plots experiment (Versailles, France). Clays and Clay Mineralogy, Scotland, v. 51, n. 5, p. 577-584, 2003.

ROSOLEM, C. A.; MACHADO, J. R.; RIBEIRO, D. B. O. Formas de potássio no solo e nutrição potássica da soja. Revista Brasileira de Ciência do Solo, Campinas, v. 12, n. 1, p. 121-125, 1988.

ROSOLEM, C. A.; SGARIBOLDI, T.; GARCIA, R. A.; CALONEGO, J. C. Potassium leaching as affected by soil texture and residual fertilization in tropical soils. Communications in Soil Science and Plant Analysis, New York, v. 41, n. 16, p. 1934-1943, 2010.

ROSOlEM, C. A.; VICENTINI, J. P. T. M. M.; STEINER, F. Suprimento de potássio em função da adubação potássica residual em um Latossolo Vermelho do Cerrado. Revista Brasileira de Ciência do Solo, Viçosa, MG, v. 36, n. 5, p. 1507-1515, 2012.

SANZONOWICZ, C.; MIELNICZUK, J. Distribuição de $\mathrm{K}$ no perfil de um solo influenciado pela planta, fontes e métodos de aplicação de adubos. Revista Brasileira de Ciência do Solo, Campinas, v. 9, n. 1, p. 45-50, 1985.

SHAIKH, K.; MEMON, K. S.; MEMON, M.; AKHTAR, M. S. Changes in mineral composition and bioavailable potassium under long-term fertilizer use in cotton-wheat system. Soil and Environmental, Pakistan, v. 26, n. 1, p. 1-9, 2007.
SILVA, D. N.; MEURER, E.; KAMPF, N.; BORKET, C. M. Mineralogia e formas de potássio em dois Latossolos do Estado do Paraná e suas relações com a disponibilidade para as plantas. Revista Brasileira de Ciência do Solo, Campinas, v. 19, n. 3, p. 433-439, 1995.

SILVA, I. R.; FURTINI NETO, A. E.; FERNANDEZ, L. A.; CURI, N.; VALE, F. R. Formas, relação quantidade/ intensidade e biodisponibilidade de potássio em diferentes Latossolos. Pesquisa Agropecuária Brasileira, Brasília, v. 35, n. 10, p. 2065-2073, 2000.

SIMONSSON, M.; ANDERSSON, S.; ANDRISTRANGEL, Y.; HILLIER, S.; MATTSSON, L.; ÖBORN, I. Potassium release and fixation as a function of fertilizer application rate and soil parent material. Geoderma, Amsterdam, v. 140, n. 1-2, p. 188-198, 2007.

SIMONSSON, M.; HILLIER, S.; ÖBORN, I. Changes in clay minerals and potassium fixation capacity as a result of release and fixation of potassium in long term field experiments. Geoderma, Amsterdam, v. 151, n. 3-4, p. 109-120, 2009.

SINGH, M.; SINGH, V. P.; REDDY, D. D. Potassium balance and release kinetics under continuous rice-wheat cropping system in Vertisol. Field Crops Research, Amsterdam, v. 77, n. 2, p. 81-91, 2002.

SOIL SURVEY STAFF. Keys to soil taxonomy. $11^{\text {th }}$ ed. Washington: USDA Natural Resources Conservation Service, 2010.

SPARKS, D. L. Bioavailability of soil potassium. In: SUMNER, M. E. (Ed.). Handbook of soil science. Boca Raton: CRC Press, 2000. p. 1-48.

SPARKS, D. L.; HUANG, P. M. Physical, chemistry of soil potassium. In: MUNSON, R. D. (Ed.). Potassium in agriculture. Madison: Soil Science Society of America, 1985. p. 201-276.

STEINER, F.; PIVETTA, L. A.; CASTOLDI, G.; COSTA, M. S. S. M.; COSTA, L. A. M. Phosphorus and potassium balance in soil under crop rotation and fertilization. Semina: Ciências Agrárias, Londrina, v. 33, n. 6, p. 2173-2186, 2012.

TEDESCO, M. J.; GIANELlO, C.; BISSANI, C. A.; BOHNEN, H.; VOLKWEISS, S. J. Análises de solos, plantas e outros materiais. 2. ed. Porto Alegre: Universidade Federal do Rio Grande do Sul/ Departamento de Solos, 1995. 174 p. (Boletim técnico, 5).

VELDE, B.; PECK, T. Clay minerals changes in the Morrow experimental plots, University of Illinois. Clays and Clay Mineralogy, Scotland, v. 50, n. 3, p. 364-370, 2002. 
VILLA, M. R.; FERNANDES, L.A.; FAQUIN, V. Formas de potássio em solos de várzea e sua disponibilidade para o feijoeiro. Revista Brasileira de Ciência do Solo, Viçosa, MG, v. 28, n. 4, p. 649-658, 2004.
WERLE, R.; GARCIA, R. A.; ROSOLEM, C. A. Lixiviação de potássio em função da textura e da disponibilidade do nutriente no solo. Revista Brasileira de Ciência do Solo, Viçosa, MG, v. 32, n. 6, p. $2297-$ 2305, 2008. 